\title{
DEVELOPMENT OF AN ONION-CROP HARVESTER
}

\section{O.A. Omar', Soha G. Abdel Hamid ${ }^{2}$ and G.A. El-Termzy ${ }^{2}$ ABSTRACT}

Mechanization of onion crop lifting is considered of great importance to reduce time, labor and cost that required in the case of hand lifting so, the main objective of the present work was to develop and manufacture a machine to be suitable for harvesting onion crop. The developed harvester is a tractor front mounted. The developed onion- harvester consists of frame, lifting device (blade and collected roller), elevator and collecting device. Experiments were carried out to evaluate the performance of the developed harvester under parameters: four depths of harvest (4- 6- 8 and $10 \mathrm{~cm})$ and four forward speeds $(0.720-0.837-0.947$ and $1.125 \mathrm{~km} / \mathrm{h})$ under 22\%moisture content of to determine field capacity and efficiency, lifting efficiency, total crop losses, power and energy consumed, and total cost requirements for harvesting onion crop. The results indicated that, the maximum field capacity was $0.180 \mathrm{fed} / \mathrm{h}$ at speed of $1.125 \mathrm{~km} / \mathrm{h}$ and the maximum field efficiency was $73.9 \%$ at speed of $0.720 \mathrm{~km} / \mathrm{h}$, it was recorded at depth of $4 \mathrm{~cm}$, compared with manual method which recorded the field capacity and field efficiency were $0.125 \mathrm{fed} / \mathrm{h}$ and $84.26 \%$, respectively. The maximum lifting efficiency and minimum total losses were 99.2\% and $1.9 \%$ obtained with the use of the developed onion harvester, compared with manual method which recorded $98.1 \%$ and 2.5\%, respectively. The minimum power and energy consumed were $10.112 \mathrm{~kW}$ and $59.5 \mathrm{~kW}$.h/fed at depth of $4 \mathrm{~cm}$ and forward speed of $0.720 \mathrm{~km} / \mathrm{h}$ obtained under onion harvester, compared with manual method which recorded $0.759 \mathrm{~kW}$ and $6.072 \mathrm{~kW} . \mathrm{h} / \mathrm{fed}$, respectively. The criterion cost for manual harvesting was $2400 \mathrm{LE} / \mathrm{fed}$. It was recommended to operate the developed harvester for harvesting onion crop at a depth harvesting of 10 $\mathrm{cm}$ and a forward speed of $0.720 \mathrm{~km} / \mathrm{h}$ where the lowest criterion cost was $674.33 \mathrm{LE} / \mathrm{fed}$, the lowest losses was $1.9 \%$, and the least energy consumed was $59.5 \mathrm{~kW} . \mathrm{h} / \mathrm{fed}$.

\footnotetext{
${ }^{1}$ Senior researcher, Ag. Eng. Res. Inst.,

${ }^{2}$ Researcher, Ag. Eng. Res. Inst.,
} 


\section{INTRODUCTION}

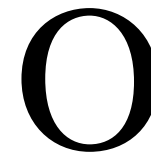
nion is the most important crop in Egypt. Harvesting process of onion crop is still carried out manually. Ashwini Talokar et al., (2014) stated that the harvesting of onion crop is rigorous and requires huge amount of manpower and time. One of the main reasons of low productivity is insufficient power availability on the farm and low level of farm mechanization. Duane Kido (2006) showed that typically bulb onions are harvested by uprooting them with a breaker bar that is pulled in the soil beneath the onions there by surfacing the bulbs. In many cases the leafy tops of these uprooted onions are manually cut before the bulbs are removed from the field. In other situations, the untopped onions are first harvested and then manually topped at the packing area. However, the manual processes are slow, expensive, and prone to injuring workers. Tapan et al., (2011) found that during the field evaluation, the prototype onion digger, performed as per the recommended standards with digging efficiency $97.7 \%$, bulb damage $3.5 \%$ and fuel consumption 4.1lit/ha. Mahesh Chand Singh (2014) developed and evaluated digger performance at the experimental site. The digger was operated with a speed of $4 \mathrm{~km} / \mathrm{h}$ in first high gear with minimum losses at a field capacity of $0.46 \mathrm{ha} / \mathrm{h}$. Depth control wheels were effective to control the depth of cut by blade. The average operational depth of $7.62 \mathrm{~cm}$ of the developed digger was suitable with practically no damage to the onion bulbs. Lift percentage, mean digger efficiency and damage percentage were $94.9,89.8$ and 5.1\%, respectively. Lee (1991) the present invention relates to machines harvesting, and particularly to machines for harvesting crops and automatically removing tops from such crop. The invention is especially adapted for use in the automatic topping and loading mechanism of an onion harvester where an air is blown through the onion plants as picked up from the field, as they are conveyed through the harvester, so as to extend the tops which grow from the plants and enable them to be cut off. The topped onion bulbs then being carried out of the machine as by being dropped onto a conveyor which carries them to a truck, cart or other transport which moves alongside the harvesting machine over the field where the onions are being harvested. The onions are harvested after the plants are dug, 
usually with an automatic digging machine. The plants are usually left on the ground, (together with their tops which grow from the onion plant) until dry. Then only dry fine soil is present on and among the crop. The crop is elevated on a conveyor to a topping region. Younus and Jayan (2015) reported that the objectives of design of the root crops harvester and the consideration was given to the following factors: The machine should achieve a reduction in the overall production cost. It should increase the productivity of farmers currently harvesting manually. It should lead to the reduction of drudgery and tedium associated with the manual process of harvesting. It is to achieve decrease losses and damage. The cost of the machine should be affordable by farmers and cheap. The machine should be adaptable to the varieties of onions. Therefore, this study aimed to harvest onion crop using a developed harvester and optimize its performance in terms of field capacity and efficiency, lifting efficiency, power, energy and finally total cost requirements.

\section{MATERIALS AND METHOD}

The main experiments were carried out through agricultural season of 2017 in Mnia El kmh farm, Sharkia Governorate to harvest onion crop using a developed harvester under Egyptian conditions. The mechanical analysis of the experimental soil was classified as a clay loam soil .The moisture content and soil bulk density of soil were $22 \%$ and $1.34 \mathrm{~g} / \mathrm{cm}^{3}$ ,respectively during the harvesting operation.

\section{1- Materials:}

\subsection{Onion crop:}

Onion is considered a perennial plant. It consists of the following two main parts: the bulb and the vegetative growth (tube leaves). Table (1) showed some physical characteristics of onion (Giza red) variety, while Fig.(1) showed a section in the soil which planted by onion crop. The bulb depth ranged between $3-9 \mathrm{~cm}$. The bed width was $90 \mathrm{~cm}$ and irrigation channel width is $25 \mathrm{~cm}$. The number of onion plant rows on the bed was 7 onions. The harvester blade depth of $10 \mathrm{~cm}$ was chosen to harvest all onion bulbs inside the soil.

\subsection{The developed front mounted onion harvesting machine:}

The harvester was developed to accomplish lifting of onion crop, lifting the soil and onion with leaves from the field and subsequently transferring 
the digging onion onto a separation unit for removing soil mass from onion and finally clean onions in the rear for manually picking up with minimum damage to the onion bulbs and leaves.

Table (1): Some physical characteristics of onion (Giza red).

\begin{tabular}{|l|c|}
\hline \multicolumn{1}{|c|}{ Characteristic } & Value \\
\hline Average diameter, $\mathrm{cm}$ & 7 \\
\hline Average length, $\mathrm{cm}$ & 5 \\
\hline Average mass, gm & 125 \\
\hline Average height of leave, $\mathrm{cm}$ & 18 \\
\hline
\end{tabular}
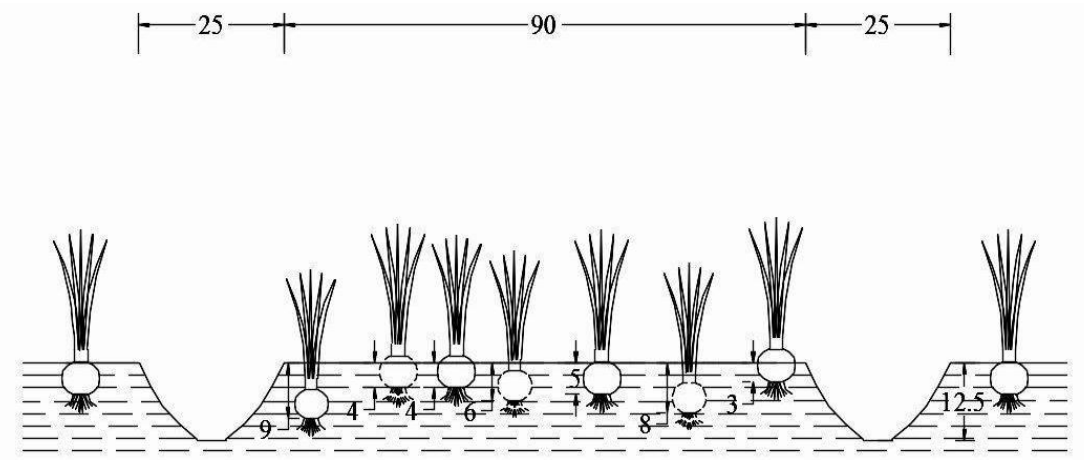

Dims. in $\mathrm{cm}$

Fig. (1): Section of the soil planted by onion crop.

The developed machine was manufactured at a local workshop. It has a hydraulic control with cutting width of $135 \mathrm{~cm}$ and mass of $310 \mathrm{~kg}$. The machine was mounted in front of the tractor, where the tractor was prepared to suit harvesting with this position to increase the machine efficiency. It is consisting of frame, lifting device, elevator device, separating device and collecting device. It is mounted and attached to the front of the tractor using 3- hitch point while the separating device is powered from the tractor PTO shaft. The machine is equipped with two depth control device to control the digging depth.

\section{- The frame}

It is the component that holds all other parts together for efficient functioning. 


\section{- The lifting device}

The lifting device consists of blade and collected roller

\section{- Blade}

It is sharpened at the edge to enhance penetration. It is made from steel section width $135 \mathrm{~cm}$ and thickness of $0.3 \mathrm{~cm}$. The blade passes under the onion to loosen and lift the bulb onions with the soil. The blade is fixed firmly to a flat bar on frame. The blade is inclined by an angle $15^{\circ}$ to the horizontal so that to lift the soil with bulb onion and throw it above the elevator device.

\section{- The collected roller.}

It is fabricated to hold the onion and push it up to the elevator device. The roller is powered from tractor PTO. It is made of steel section and include 21 fingers arranged in three rows to pick the onion. It is fixed above the blade then passes the soil and onions into rapidly rotation to the elevator.

\section{- The elevator and separation devices.}

It includes 40 spherical steel rods $0.7 \mathrm{~cm}$ diameter. The distance between each two rods is $4 \mathrm{~cm}$. The conveyor is held in two shafts and powered from tractor PTO. The elevator consists of a share, which raises the soil into apron of steel rods or separate chains. The soil fall off as the crop moves to the back of the elevator that is given a shaken action and the onions bulb are returned to the ground for hand picking.

\section{- Collecting device}

It consists of two reflectors which collected the onions bulb in row behind the machine between the two wheels of the tractor. It is made from steel section and fixed above the elevator web from the two sides under the collected roller

\subsection{Tractor:}

- Tractor was used as a power source to operate and mounte the used equipment.

Agro master brand

Model :

TST. 450AC

Max. power : $\quad 33 \mathrm{~kW}(45 \mathrm{hp})$

Rated power : $\quad 29.4 \mathrm{~kW}(40 \mathrm{hp})$

Made in : china 


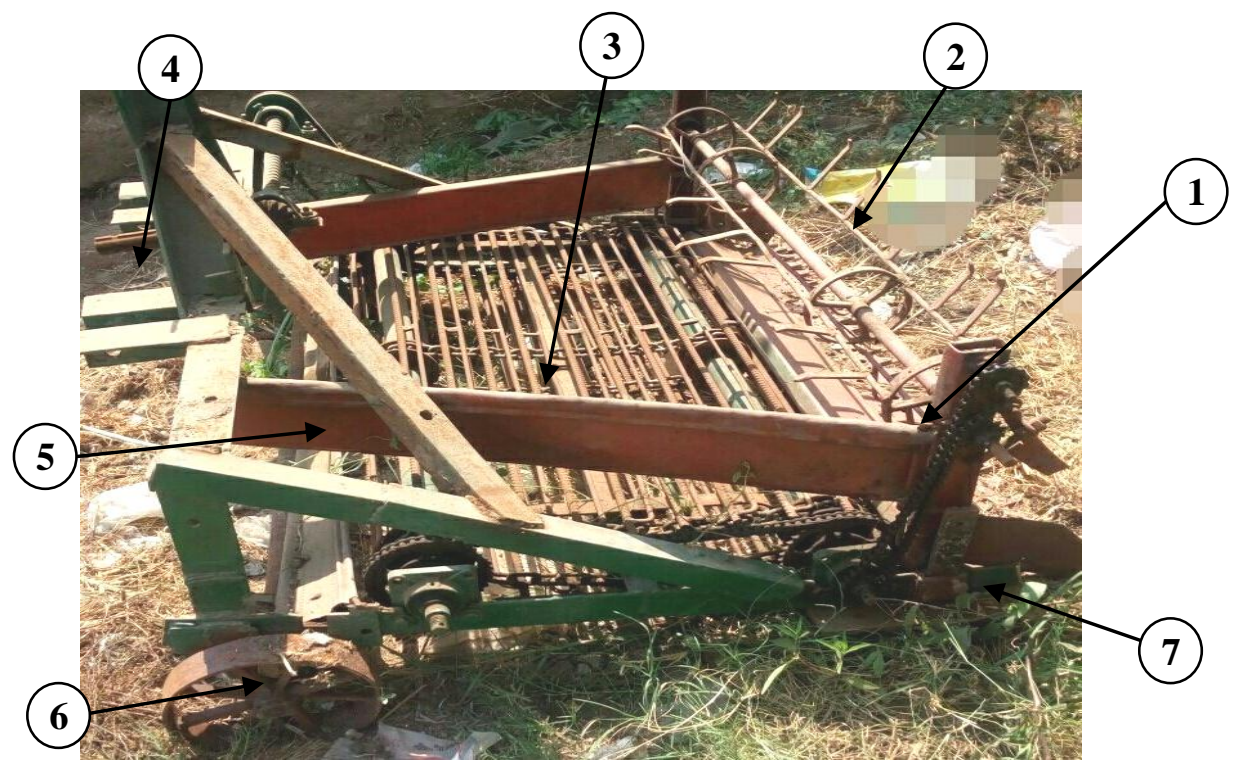

\begin{tabular}{|l|c|c|c|}
\hline 1 & Blade & 5 & Collecting plate \\
\hline 2 & The collected roller & 6 & Wheel \\
\hline 3 & The elevator & 7 & Depth control device \\
\hline 4 & P.T.O. shaft & \multicolumn{2}{|c}{} \\
\cline { 1 - 2 } & & &
\end{tabular}

Fig. (2): Photograph of the developed onion harvester.

\section{2- Methods:}

\subsection{Experimental conditions:}

- Harvesting manual was carried out using 24 labor/feddan with average wage $75 \mathrm{LE} /$ labor in the work day.

- Harvesting mechanical was carried out using the developed onion harvesting machine. The harvesting operation was carried out through four different depths of 4, 6, 8 and $10 \mathrm{~cm}$ and four different forward speeds of $0.720,0.837,0.947$ and $1.125 \mathrm{~km} / \mathrm{h}$.

\subsection{Measurements:}

\section{- Soil mechanical analysis:}

Eight random samples were taken to determine soil mechanical analysis using the hydrometer method.

\section{- Onion dimensions:}

The bulb length (L), diameter of bulb (D) and height of leaves (H) were measured and recorded for random samples of onion plant before harvesting operation. Showed in table (1) 

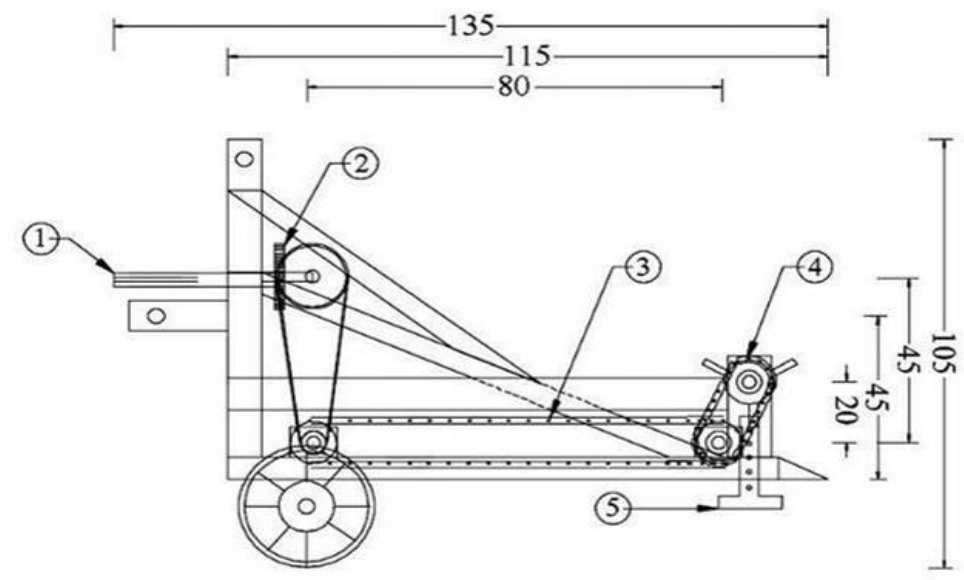

Elevation view

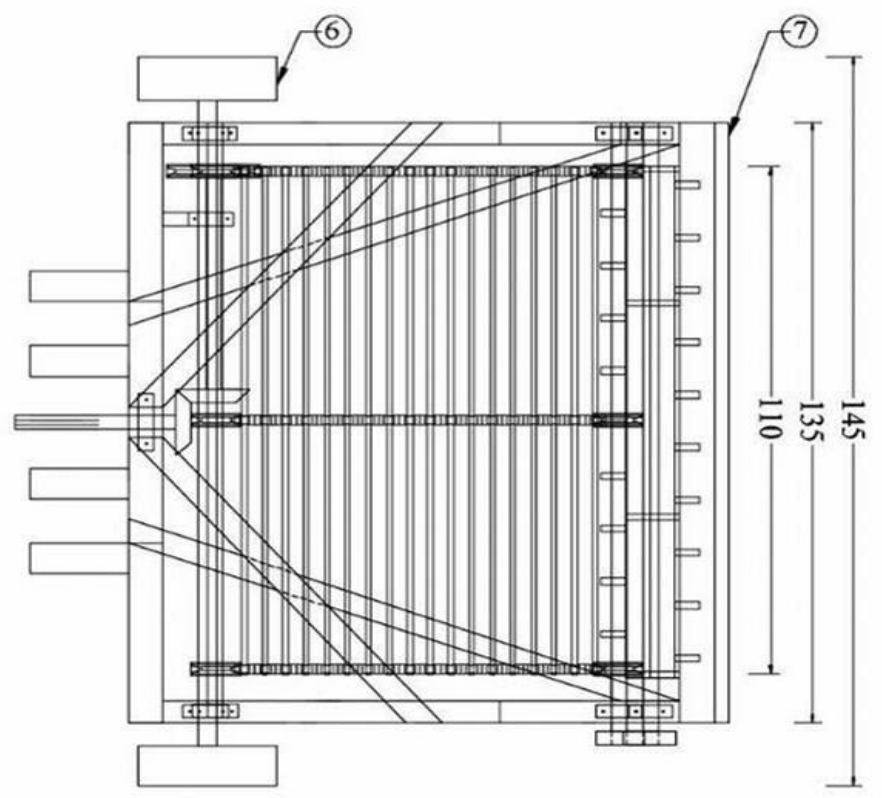

Plan

Dims. in $\mathrm{cm}$

\begin{tabular}{|l|c|c|c|}
\hline 1 & P.T.O. shaft & 5 & Depth control device \\
\hline 2 & Gear & 6 & Wheel \\
\hline 3 & The elevator & 7 & Blade \\
\hline 4 & The collected roller & & \\
\hline
\end{tabular}

Fig. (3): Views of the developed front mounted onion-harvester. 


\section{- Onion mass:}

Mass of plant (bulb and leaves) was measured and ratio of bulb mass to the vegetative growth mass was also calculated for all treatments under test.

\section{- Bulb yield:}

The yield of the harvested bulbs was determined by massing the lifted bulbs by using the following equation (Taieb, 1997):

$$
R_{\mathrm{Y}}=\frac{\mathrm{M} \times 4200}{\mathrm{~A} \times 1000}(\mathrm{Mg} / \mathrm{fed}),
$$

Where:

$M=$ Mass of lifted bulbs, $\mathrm{kg}$.

$A=$ Harvested area, $\mathrm{m}^{2}$.

\section{- Field capacity:}

Actual field capacity was the actual average time consumed during digging operation (lost time + productive time). It can be determined from the following equation:

$$
F . C_{a c t}=\frac{60}{T u+T i}, \quad(\mathrm{fed} / \mathrm{h})
$$

Where:

F. $C_{a c t}=$ Actual field capacity of the cutting machine.

$T_{u}=$ Utilization time per feddan in minutes.

$T_{i}=$ Summation of lost time per feddan in minutes.

\section{- Field efficiency:}

Field efficiency is calculated by using the values of the theoretical field capacity and effective field capacity rates as:

$$
\eta_{f}=\frac{F \cdot C_{a c t}}{F \cdot C_{t h}} \times 100(\%),
$$

Where: 
$\eta_{f}=$ Field efficiency, $\%$.

\section{- Total losses:}

Total onion losses can be calculated using the following equation:

Total losses $=$ Mass of unlifted onions + Mass of damaged onions

\section{- Lifting efficiency:}

The lifting efficiency was calculated according to the following equation:

$$
L_{e}=\frac{M_{L}}{M_{\mathrm{T}}} \times 100
$$

Where:

$L_{e}=$ Lifting efficiency, $\%$.

$M_{L}=$ Mass of lifted onions, $\mathrm{kg}$.

$M_{T}=$ Total mass of onions (lifted + un-lifted), $\mathrm{kg}$.

\section{- Required power and specific energy:}

To estimate the required power during digging operation, the decrease in fuel level in fuel tank was accurately measured immediately after each treatment. The following formula was used to estimate the engine power (Hunt, 1983):

$E P=\left[f . c(1 / 3600) \rho E \times L . C . V \times 427 \times \eta_{t h b} \times \eta_{m} \times 1 / 75 \times 1 / 1.36\right], k W$

here:-

$E p=$ Required power, $(\mathrm{kW})$.

$f . c=$ Fuel consumption, $(1 / \mathrm{h})$.

$\rho E=$ Density of fuel, $(\mathrm{kg} / \mathrm{l}),($ for Gas oil $=0.85)$.

L.C.V = Calorific value of fuel, $(11.000 \mathrm{kcal} / \mathrm{kg})$.

$\eta_{t h b}=$ Thermal efficiency of the engine, (35\% for Diesel engine).

$427=$ Thermo-mechanical equivalent, $(\mathrm{kg} \cdot \mathrm{m} / \mathrm{kCal})$.

$\eta_{m}=$ Mechanical efficiency of the engine, (80\% for Diesel engines).

So, the specific energy can be calculated as following: 
Specific energy $=\frac{\text { required power },(k W)}{\text { Field capacity },(\text { fed } / h)},(k W . h /$ fed $)$.

\section{- Cost analysis:}

Hourly cost was determined using the following equation (Awady, 1978):

$$
C=\frac{P}{h}\left(\frac{1}{a}+\frac{i}{2}+t+r\right)+(0.9 \text { W.S.F })+\frac{m}{144},(\text { L.E } / h) .
$$

Where:

$C=$ Hourly cost, L.E/h. $\quad P=$ Price of machine, L.E.

$h=$ Yearly working hours, h/year. $\quad a=$ Life expectancy of the machine, h.

$i=$ Interest rate/year. $\quad F=$ Fuel price, L.E/l.

$t=$ Taxes, over heads ratio. $\quad r=$ Repairs and maintenance ratio.

$m=$ The monthly average wage, L.E $\quad 0.9=$ Factor accounting for lubrications.

$W=$ Engine power, $\mathrm{hp} . \quad S=$ Specific fuel consumption, $1 / \mathrm{hp} . \mathrm{h}$.

$144=$ Reasonable estimation of monthly working hours.

Operational cost can be determined using the following equation:

Operating $\cos t=\frac{\text { Hourly } \cos t(L . E / h)}{\text { Actual field capacity }(\text { fed } / h)},($ L.E / fed $)$.

Criterion cost can be determined using the following equation:

Criterion cost $($ L.E/fed $)=$ Operational cost + Losses cost.

\section{RESULTS AND DISCUSSION}

The discussion will cover the obtained results under the following headings:

\section{1- Effect of forward speed and depth of harvest on field capacity and efficiency.}

Field capacity and field efficiency are highly affected by machine effective width, forward speed, soil moisture content and field conditions.

Results in Fig (4) show a remarkable drop in the field efficiency with a consequent sharp rise in the actual field capacity as the forward speed increased. 
Increasing forward speed from 0.720 to $1.125 \mathrm{~km} / \mathrm{h}$ leads to increase actual field capacity, the maximum field capacity was $0.180 \mathrm{fed} / \mathrm{h}$ at $1.125 \mathrm{~km} / \mathrm{h}$ and depth of $4 \mathrm{~cm}$, meanwhile the minimum value was $0.167 \mathrm{fed} / \mathrm{h}$ at $0.720 \mathrm{~km} / \mathrm{h}$ at depth of $10 \mathrm{~cm}$. By increasing the depth of harvest from 4 to $10 \mathrm{~cm}$ the field capacity values decreased from 0.170 to $0.167 \mathrm{fed} / \mathrm{h}$, from 0.172 to $0.169 \mathrm{fed} / \mathrm{h}$, from 0.176 to $0.171 \mathrm{fed} / \mathrm{h}$ and from 0.180 to $0.174 \mathrm{fed} / \mathrm{h}$ at $0.720,0.837,0.947$ and $1.125 \mathrm{~km} / \mathrm{h}$ forward speed, respectively.
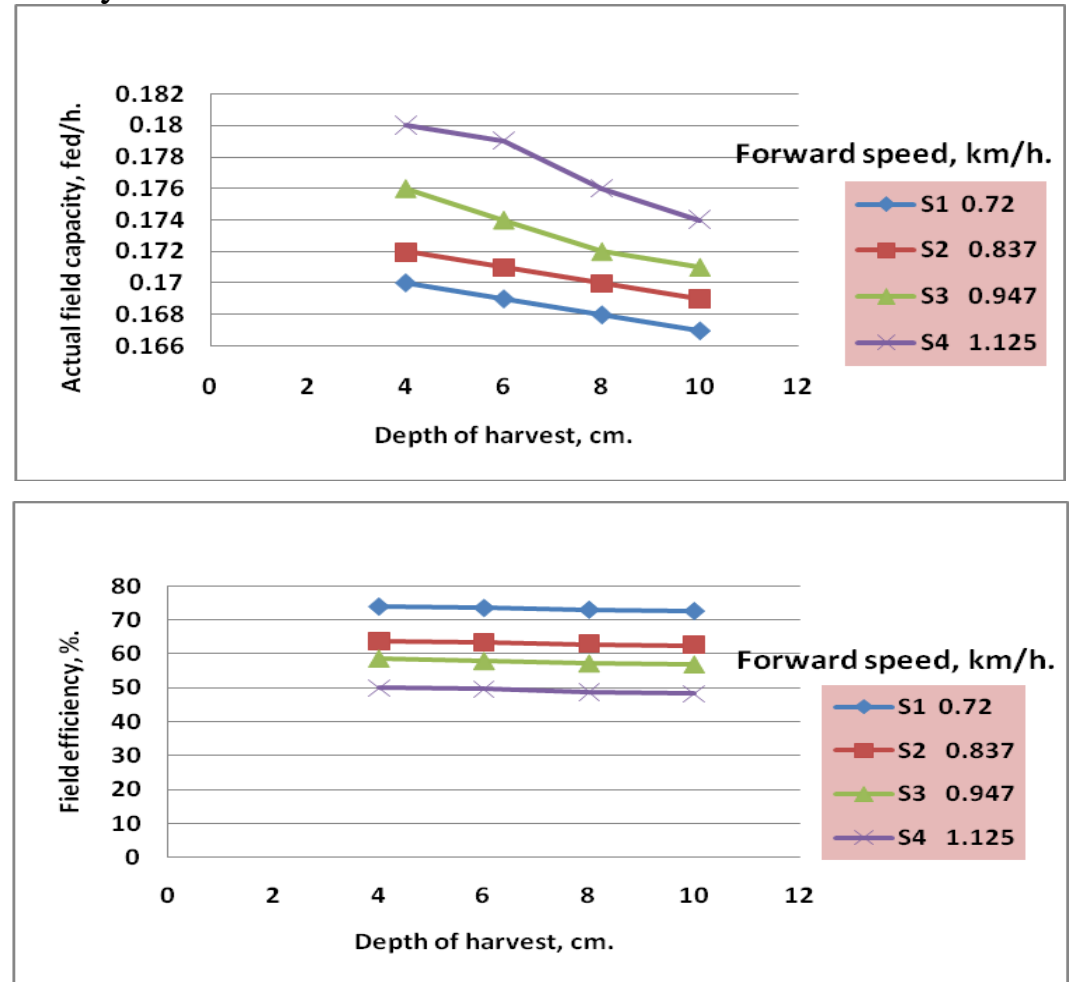

Fig. (4): Effect of forward speed and depth of harvest on field capacity and efficiency.

On the other hand, increasing forward speed from 0.720 to $1.125 \mathrm{~km} / \mathrm{h}$ decreased field efficiency, the maximum field efficiency was $73.9 \%$ at $0.720 \mathrm{~km} / \mathrm{h}$ and $4 \mathrm{~cm}$ depth, while the minimum field efficiency was $48.3 \%$ at $1.125 \mathrm{~km} / \mathrm{h}$ and $10 \mathrm{~cm}$ depth. By increasing the depth of harvest from 4 to $10 \mathrm{~cm}$ field efficiency decreased from 73.9 to $72.6 \%$, from 63.7 to $62.5 \%$, from 58.7 to $57.0 \%$ and from 50.0 to $48.3 \%$ at $0.720,0.837,0.947$ and $1.125 \mathrm{~km} / \mathrm{h}$ forward speed, respectively. The major reason for the 
reduction in field efficiency by increasing forward speed may be due to the increasing maintenance requirement by increasing depth and increasing the quantity of soil on the elevator device. Meanwhile with manual harvesting, the field efficiency value was $87.5 \%$.

\section{2- Effect of forward speed and depth of harvest on un-lifted and damaged onions:}

Fig.(5) showed that increasing machine forward speed from 0.720 to $1.125 \mathrm{~km} / \mathrm{h}$ decreased un-lifted onion values, the maximum value was $1.7 \%$ at $0.720 \mathrm{~km} / \mathrm{h}$, while the minimum value was $0.8 \%$ at $1.125 \mathrm{~km} / \mathrm{h}$. With increasing the depth of harvest between 4 to $10 \mathrm{~cm}$ decreased unlifted values from 1.7 to $1.1 \%$, from 1.6 to $0.98 \%$, from 1.5 to $0.92 \%$ and from 1.3 to $0.8 \%$ under forward speed of $0.720,0.837,0.947$ and 1.125 $\mathrm{km} / \mathrm{h}$, respectively.
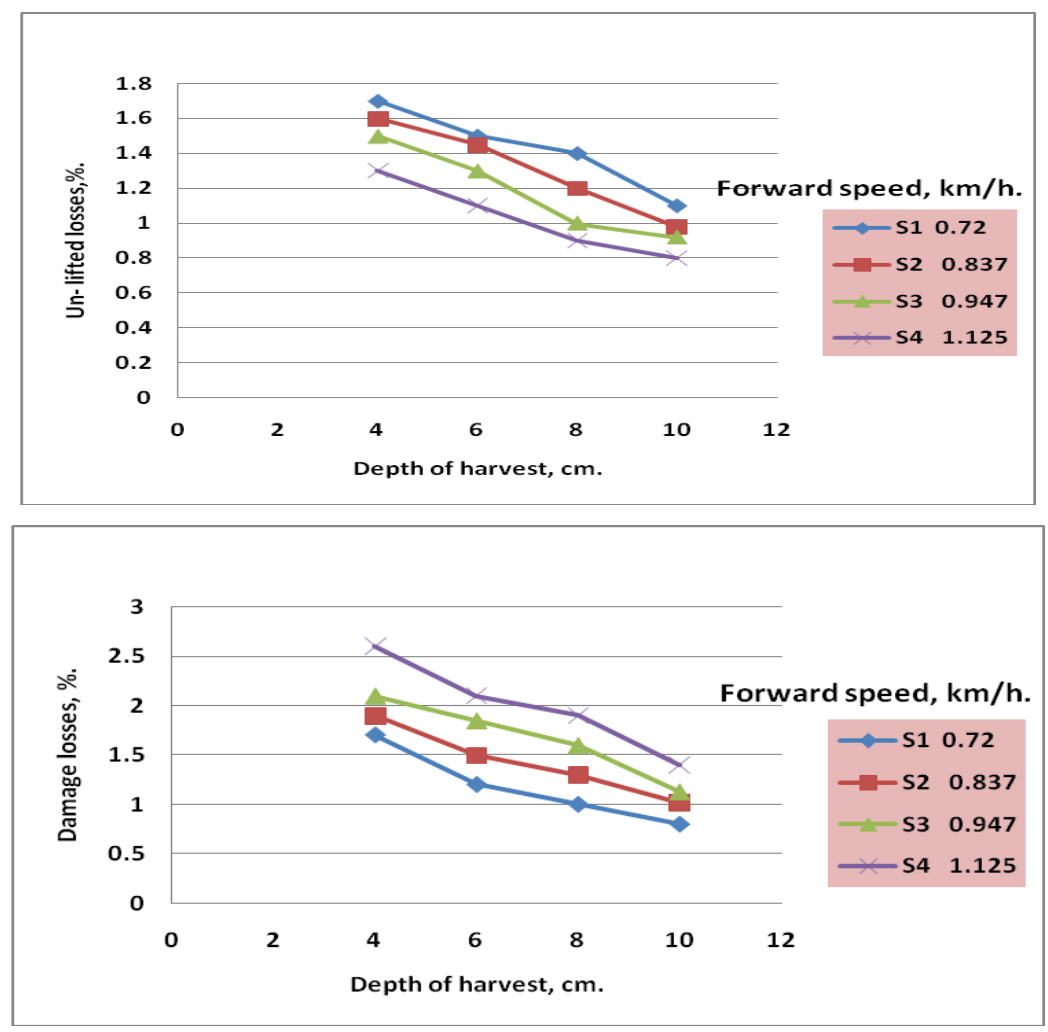

Fig. (5): Effect of forward speed and depth of harvest on the un-lifted and damaged onions. 
While the un-lifted bulbs of $1.9 \%$ using manual harvesting. On the other hand by increasing machine forward speed from 0.720 to $1.125 \mathrm{~km} / \mathrm{h}$ increased the damaged onion bulbs values and with increasing the depth of harvest from 4 to $10 \mathrm{~cm}$ decreased the damaged onion bulbs values, the maximum value was $2.6 \%$ at $1.125 \mathrm{~km} / \mathrm{h}$ and $4 \mathrm{~cm}$ depth of harvest, while the minimum value was 0.8 at $0.720 \mathrm{~km} / \mathrm{h}$ and $10 \mathrm{~cm}$ depth of harvest for the developed harvester. Meanwhile with manual harvesting damaged bulbs of $0.6 \%$ was recorded.

\section{3-Effect of forward speed and depth of harvest on the total losses and lifting efficiency.}

Fig. (6) showed that the increasing of forward speed from 0.720 to 1.125 $\mathrm{km} / \mathrm{h}$ increased the total losses, the maximum total losses was $3.9 \%$ at $1.125 \mathrm{~km} / \mathrm{h}$, while the minimum was $1.9 \%$ at $0.720 \mathrm{~km} / \mathrm{h}$. By increasing the harvesting depth from 4 to $10 \mathrm{~cm}$ decreased the total losses values from 3.4 to $1.9 \%$, from 3.5 to $2.0 \%$, from 3.6 to $2.05 \%$ and from 3.9 to $2.2 \%$ at $0.720,0.837,0.947$ and $1.125 \mathrm{~km} / \mathrm{h}$ forward speed, respectively. While with manual harvesting losses was $2.5 \%$. Meanwhile by increasing the forward speed from 0.720 to $1.125 \mathrm{~km} / \mathrm{h}$ increased the lifting efficiency, the maximum lifting efficiency was $99.2 \%$ at $1.125 \mathrm{~km} / \mathrm{h}$, while the minimum was $98.3 \%$ at $0.720 \mathrm{~km} / \mathrm{h}$. By increasing the harvesting depth from 4 to $10 \mathrm{~cm}$ increased the lifting efficiency from 98.3 to $98.9 \%$, from 98.4 to $99.02 \%$, from 98.5 to $99.08 \%$ and from 98.7 to $99.2 \%$ under forward speed of $0.720,0.837,0.947$ and $1.125 \mathrm{~km} / \mathrm{h}$, respectively for the developed harvester. Meanwhile the manual harvesting lifting efficiency was $99.1 \%$. This is may be due to decreasing un- lifted onion ratio by increasing the forward speed.

\section{4- Effect of forward speed and depth of harvest on the power and specific energy.}

Fig. (7) showed that the power consumption increased by increasing forward speed from 0.720 to $1.125 \mathrm{~km} / \mathrm{h}$ and increasing the depth of harvest from 4 to $10 \mathrm{~cm}$, the maximum power required $19.37 \mathrm{~kW}$ was at $1.125 \mathrm{~km} / \mathrm{h}$ forward speed and $10 \mathrm{~cm}$ harvesting depth, meanwhile the minimum power required $10.112 \mathrm{~kW}$ was at $0.720 \mathrm{~km} / \mathrm{h}$ forward speed and $4 \mathrm{~cm}$ harvesting depth for the developed harvester. 

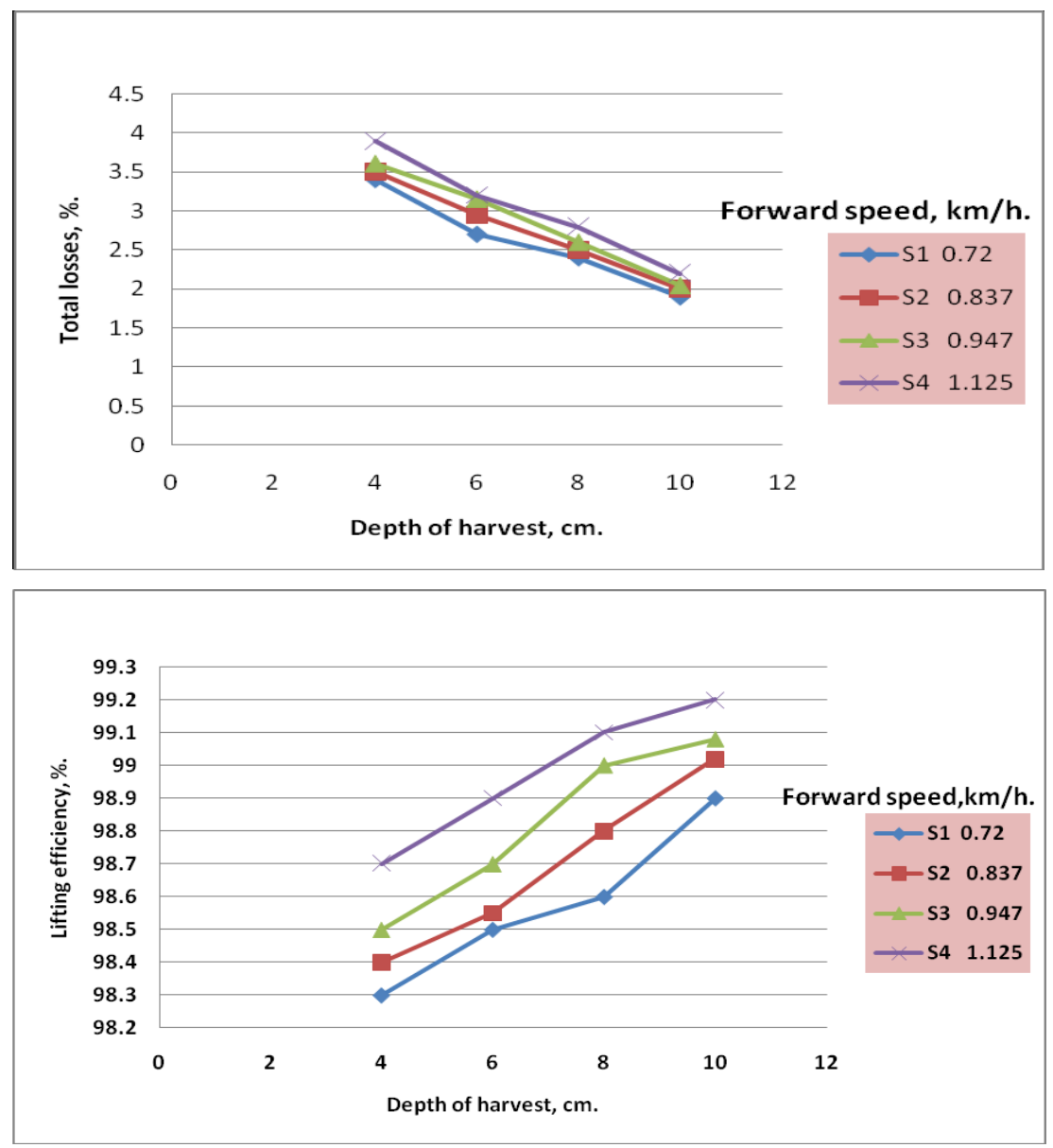

Fig. (6): Effect of forward speed and depth of harvest on the total losses and lifting efficiency

Meanwhile the manual harvesting power consumed was $0.759 \mathrm{~kW}$. And the energy requirement values increased by increasing forward speed from 0.720 to $1.125 \mathrm{~km} / \mathrm{h}$ and by increasing the depth of harvest from 4 to $10 \mathrm{~cm}$, the maximum energy requirement value was $111.32 \mathrm{~kW} . \mathrm{h} / \mathrm{fed}$ at $1.125 \mathrm{~km} / \mathrm{h}$ forward speed and $10 \mathrm{~cm}$ harvesting depth, meanwhile the minimum energy requirement value was $59.5 \mathrm{~kW}$.h/fed at forward speed of $0.720 \mathrm{~km} / \mathrm{h}$ and $4 \mathrm{~cm}$ harvesting depth for the developed harvester. This attributed to increasing of the fuel consumption, power required rate is higher than increasing in the productivity rate. By the way manual harvesting the energy requirement was $6.072 \mathrm{~kW} . \mathrm{h} / \mathrm{fed}$. 

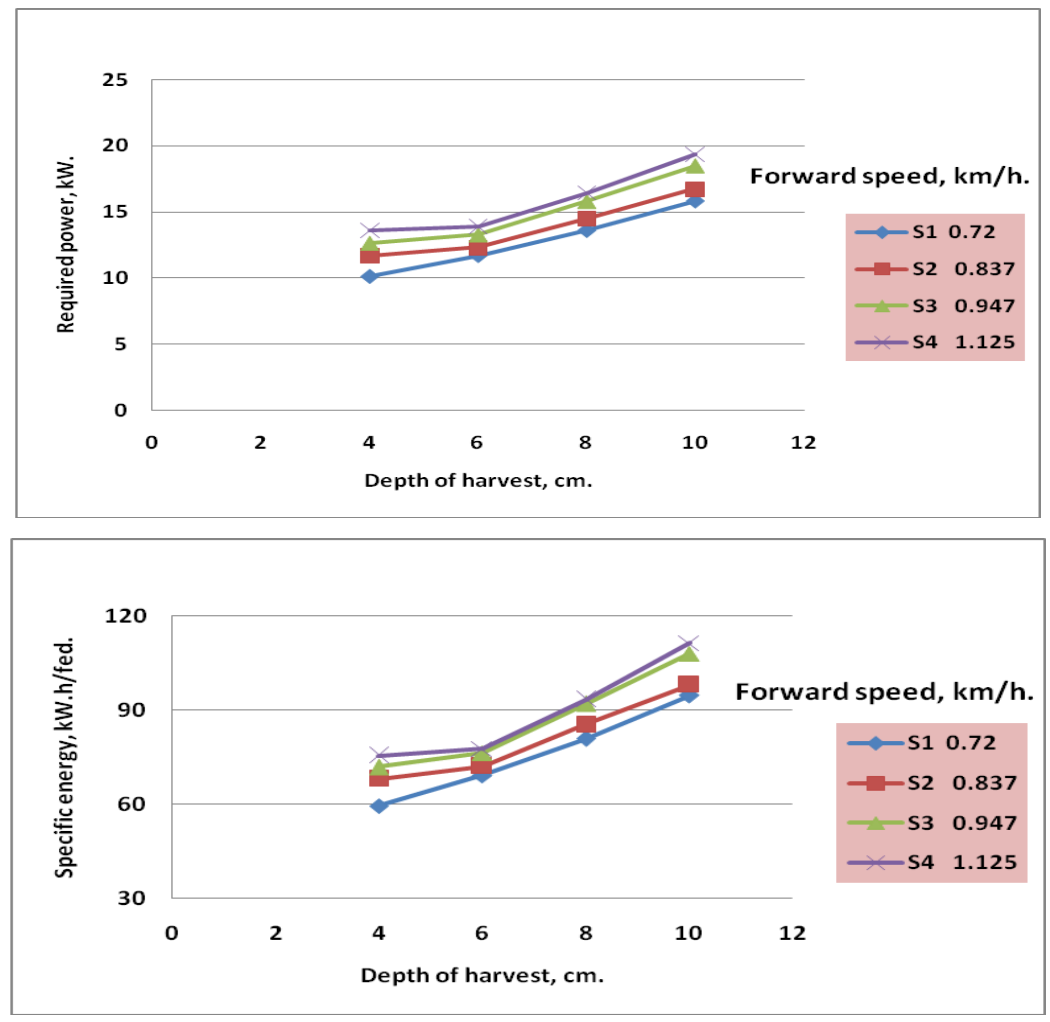

Fig. (7): Effect of forward speed and depth of harvest on power and specific energy.

\section{5- Effect of onion harvesting method on operational and criterion costs.}

The operational cost and the criterion cost values of manual harvesting were 1800LE/fed and 2400 L.E/fed under manual harvesting. Results in Fig (8) showed that, for developed front onion harvester the operational cost increasing with increased forward speed and depth of harvest. Increasing forward speed from 0.720 to $1.125 \mathrm{~km} / \mathrm{h}$, the operational cost values increased, the operational cost values decreased from 194.9 to $191.1 \mathrm{LE} / \mathrm{fed}$, from 198.4 to $193.1 \mathrm{LE} /$ fed, from 206.2 to $203.2 \mathrm{LE} /$ fed and from 218.3 to $212.2 \mathrm{~L} . \mathrm{E} / \mathrm{fed}$ at depths of harvest $4,6,8$ and $10 \mathrm{~cm}$, respectively. On the other hand the criterion cost increased with increasing forward speed and decreasing with increasing depth of harvest. Increasing forward speed from 0.720 to $1.125 \mathrm{~km} / \mathrm{h}$ lead to increased the criterion cost from1010.9 to 1127.1 LE/fed at depth of harvest $4 \mathrm{~cm}$. With increasing the depth of harvest from 4 to $10 \mathrm{~cm}$ the values decreased from 1010.9 to $674.3 \mathrm{LE} / \mathrm{fed}$, from 1032.8 to 
694.3 LE/fed, from 1057.06 to $705.2 \mathrm{LE} /$ fed and from 1127.1 to 740.2 $\mathrm{LE} / \mathrm{fed}$ under forward speeds of $0.720,0.837,0.947$ and $1.125 \mathrm{~km} / \mathrm{h}$, respectively. This is due to the decreasing of total losses percentage with increasing the depth of harvest and increasing lifting efficiency.

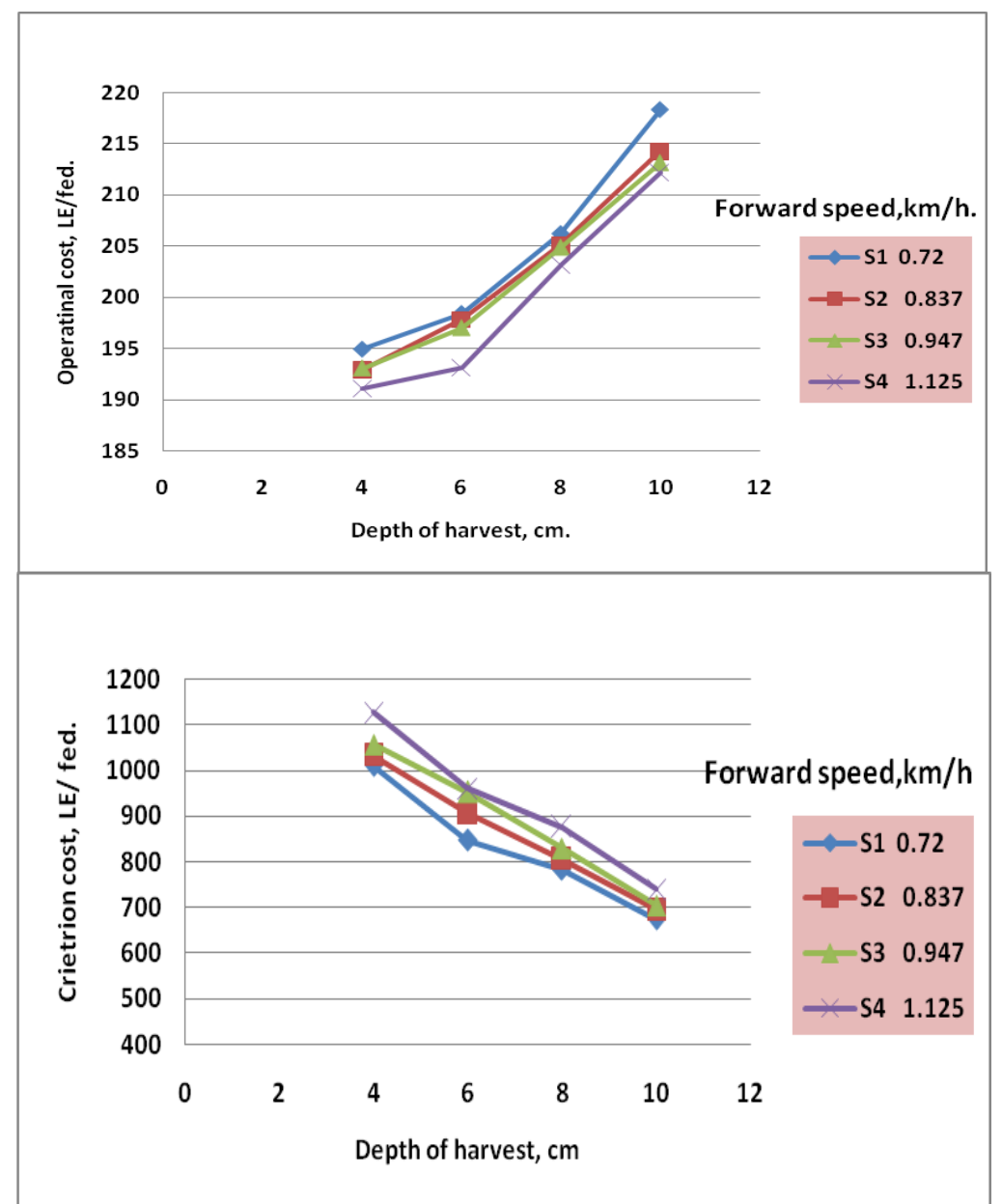

Fig. (8): Effect of forward speed and depth of harvest on operational and criterion costs.

\section{CONCLUSION}

The experimental results reveal that the total crop losses as well as harvesting cost are minimum and lifting efficiency is maximum with the use of the developed harvester under the following conditions:

- Harvesting onion crop at depth of $10 \mathrm{~cm}$.

- Harvester forward speed of $0.720 \mathrm{~km} / \mathrm{h}$. 


\section{REFERANCES}

Ashwini, T.; K., Wankhade and V.P. Khambalkar (2014). Design of onion harvester . January 24, Yuva Engineers Agricultural Engineering.

Awady, M.N. (1978). Tractor and farm machinery. Arabic Txtbk., Col. Ag., Ain Shams Univ., 164-167.

Duane Kido, P.O. and I.D., Parma, David Shuff (2006). Onion harvester with leaf topper. Patent No. US7, 007,449 Bz

Hunt, D. (1983). Farm power and machinery management. $8^{\text {th }}$ Ed. Iowa state Univ., Press Ames, USA. Ames, Iowa, USA: 364-368.

Lee N. Shuknecht (1991). Harvesting machine having blower damage prevention means US 5024278 A.

Mahesh C.S. (2014). Development and performance evaluation of a digger for harvesting onion (Allium Cepa L.). International Journal of Agric. Eng. 7(10): 391- 394.

Taieb, A.Z. (1997): Comparative study on manual and mechanical sugar beet planting in the newly reclaimed lands. Misr. J. Ag. Eng., 14 (3): 299-309.

Tapan, K.K.; I., Mani and A.P., Srivastava (2011). Designed and developed of tractor drawn onion (Allium Cepa) harvester. Indian Journal of Agr. Sciences 81(6): 528- 532

Younus, A. and P.R. Jayan (2015). Performance evaluation of root crop harvesters. International Journal of Engineering Research and Development. Volume 11, Issue

$$
\begin{aligned}
& \text { الملخص العربي }
\end{aligned}
$$

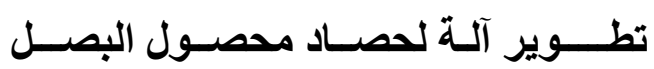

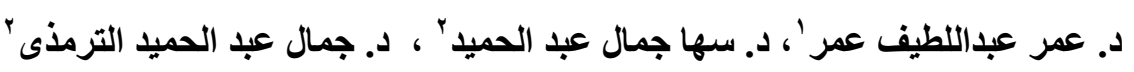

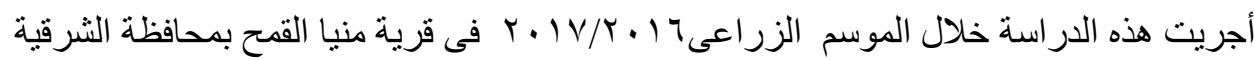

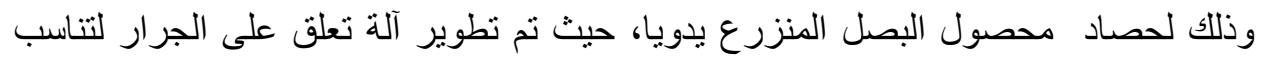

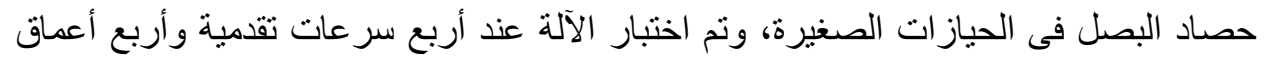

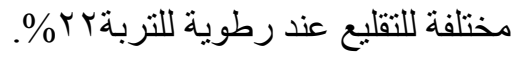

$$
\begin{aligned}
& \text { ' باحث أول بمعهد بحوث الهندسة الزراعية ـ مركز البحوث الزراعيةـ الدقى - مصر. }
\end{aligned}
$$

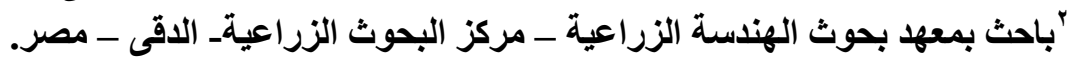


وكاتت أهداف الدراسة كالآتى:

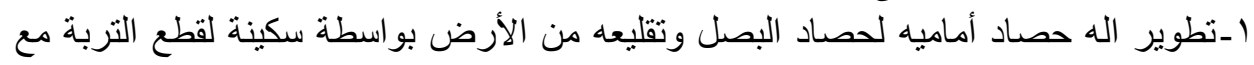

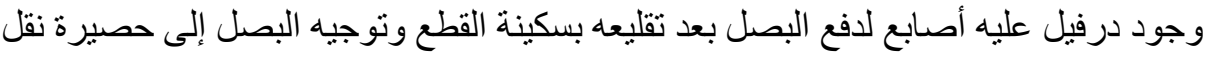

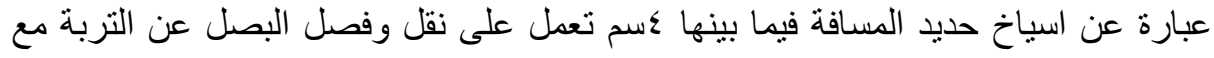
وجود الو اح توجيه لتجميع البصل فى شريط ذو عرض لـ آ سم وسقوطه بين عجل الجرار لتقليل فاقد التلف الميكانيكى.

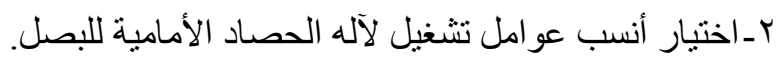

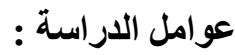

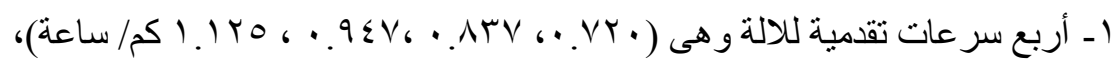

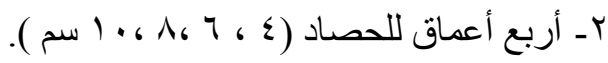

النتائج المتحصل عليها: إستخدام آلة الحصاد المطورة أدى الى لزيادة كفاءة الحصاد وزيادة معدل الأداء وتقليل فاقد

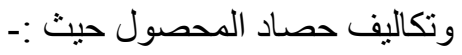

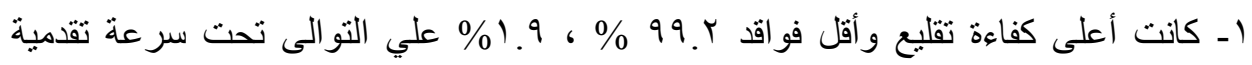

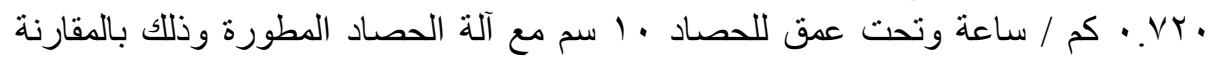

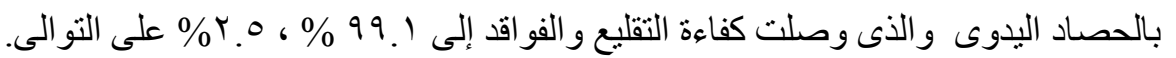

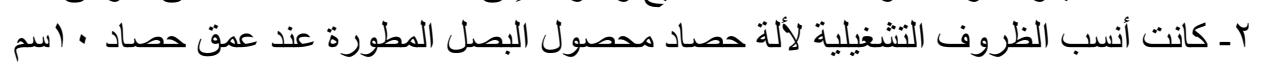

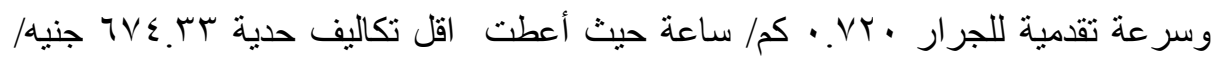

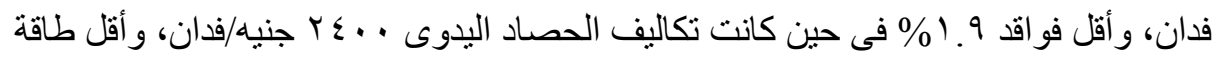

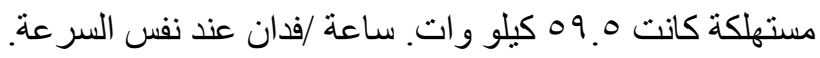

